\title{
Language Contact and Lexical Change: A Lexicographical Terminographical Interface in Zimbabwean Ndebele*
}

\author{
Langa Khumalo, Ndebele Lexicography Unit, African Languages Research \\ Institute (ALRI), University of Zimbabwe, Harare, Zimbabwe \\ (langa@arts.uz.ac.zw)
}

\begin{abstract}
In this article linguistic changes and/or developments in the Ndebele language spoken in Zimbabwe are investigated and analyzed and the implications these have for term creation and standardization through lexicography. This is followed by a brief historical analysis of the nature and causes of language change in Ndebele. The first part of the article gives a brief background of the Ndebele language, highlighting the movement of the Ndebele people from South Africa which provided a fertile ground for the process of language contact and therefore language change. The second part of the article contrasts terminography with lexicography. The Ndebele corpus of both spoken and written material demonstrates a large extent of borrowing and also loss of certain lexical items. Ndebele lexicograpers were expected to introduce some terms for the purposes of popularizing their use and consequently their acceptance.
\end{abstract}

Keywords: NDEBELE, LANGUAGE CONTACT, LEXICAL CHANGE, VOCABULARY CHANGE, LEXICAL ENGINEERING, LEXICOGRAPHY, TERMINOGRAPHY

Opsomming: Taalkontak en leksikale verandering: 'n Leksikografiese terminografiese koppelvlak in Zimbabwiese Ndebele. In hiedie artikel word linguistiese veranderinge en/of ontwikkelinge in die Ndebeletaal wat in Zimbabwe gepraat word, ondersoek en ontleed, en die implikasies wat dit vir taalskepping en standaardisering deur die leksikografie het. Die eerste deel van die artikel gee 'n kort agtergrond van die Ndebeletaal, met beklemtoning van die beweging van die Ndebelevolk vanaf Suid-Afrika wat ' $n$ vrugbare grond vir die proses van taalkontak en gevolglik taalverandering verskaf het. Dit word gevolg deur 'n kort historiese ontleding van die aard en oorsake van taalverandering in Ndebele. Die tweede deel van die artikel stel terminografie teenoor leksikografie. Die Ndebelekorpus van sowel gesproke as geskrewe materiaal laat blyk 'n groot omvang van ontlening en ook 'n verlies van sekere leksikale items. Van Ndebeleleksikograwe is verwag om sekere terme op te neem met die doel om hul gebruik te populariseer en gevolglik hul aanvaarding te bewerkstellig.

* This article was presented as a paper at the Seventh International Conference of the African Association for Lexicography, organised by the Dictionary Unit for South African English, Rhodes University, Grahamstown, 8-10 July 2002. It owes its scope to the following works: Hadebe (2001), Hadebe (2002), from where the article draws most of its examples, and Khumalo (2001). 
Sleutelwoorde: NDEBELE, TAALKONTAK, LEKSIKALE VERANDERING, WOORDESKATVERANDERING, LEKSIKALE AANPASSING, LEKSIKOGRAFIE, TERMINOGRAFIE

\section{Introduction}

The article investigates and analyses linguistic changes and/or developments that the Ndebele language, spoken in Zimbabwe, might have undergone from its earliest attested form to its present-day form and the implications these have in term creation and standardization through lexicography. Language change is oftentimes viewed as obvious and at the same time mysterious. The Ndebele of the past is very different from the modern Ndebele. The existence of such differences between early and later variants of the same language raises questions about how and why languages change over time. This article will make a very brief historical analysis of the nature and causes of language change in Ndebele. Ndebele has seen many modifications to its lexicon. The article will therefore focus on lexical change in Ndebele.

The first part of this article will give a brief background of the Ndebele language. It will highlight the movement of the Ndebele people from South Africa where they had linguistic contact with, among other language groups, the Zulus, Xhosas, Swatis, Sothos, and the Afrikaners. Later in Zimbabwe the Ndebeles had further contact with the Kalangas, Shonas, Vendas, Nambyas, Tswanas, and Tongas whom they subjugated and incorporated into their political system. Even later, they had further contact with English and the technological advancement it brought with it. From a linguistic point of view, the above scenario provides a fertile ground for the process of language contact and therefore language change.

The second part of the article will contrast terminography with lexicography. Although they seemingly have much in common, they also differ greatly. The specialized nature of the lexical items studied in terminography gives the discipline its own distinguishing features. In 2001, Ndebele lexicographers produced their first corpus-based monolingual dictionary Isichazamazwi SesiNdebele, henceforth referred to as the ISN. The Ndebele corpus of both spoken and written material demonstrates a large extent of borrowing and also loss of certain lexical items in the Ndebele lexical inventory as a result of reasons stated above. The article will finally demonstrate that Ndebele lexicograpers were expected to introduce terms for the purpose of popularizing their use and consequently effecting their acceptance, since some of them can no longer be excluded from the Ndebele vocabulary.

\section{Historical Background of the Ndebele People and Language}

The history of the Ndebele language is closely intertwined with the history of the Ndebele people themselves. It is difficult to discuss one without discussing 
the other. The Ndebeles are a Bantu people found mainly in the western parts of Zimbabwe. Their language belongs to the Nguni sub-group of the Bantu language family. Some Nguni languages are Zulu, Xhosa, Swati and South African Ndebele. The history of the Ndebele people and their language isiNdebele dates back to the 1820s when the people who are today known as the Ndebele, broke away from the then mighty Zulu kingdom, in the present-day province of KwaZulu-Natal in South Africa. The tale of Mzilikazi's fight with Tshaka and the subsequent migration of him and his followers from Zululand is not only well documented but is also well known and treasured by both the Zulu and the Ndebele people. The original group that left Zululand was initially called the Khumalo, as their leader, Mzilikazi, was from the Khumalo clan. When and why the group was later renamed Ndebele is a subject that has been debated without convincing conclusions, partly because the subject is full of half-truths and myths. The issue is further complicated by the fact that by then the Ndebele people had not developed or adopted any writing system from which the various claims being made can be verified (Khumalo 2004).

Mzilikazi and his Khumalos, as they were known, then moved northwards from Zululand into Sotho territory (in the present-day province of Gauteng in South Africa). Mzilikazi assimilated a number of Sotho people either through persuasion or coercion or by employing both means. What can be ascertained now is that the Sotho people soon outnumbered the original Khumalos who were of Nguni origin and consequently the group ceased to be referred to as the Khumalos. The Sotho referred to all raiding Nguni tribes as kiMatebele (meaning 'warriors with long shields'), and hence the name Matebeles for the Ndebeles, as well as the Ndebele provinces of Matabeleland. How the name Ndebele was derived from Matebele is still a controversy in historical and linguistic studies on Ndebele, that is, if the name derives from it at all (see Hadebe 2002).

The Ndebele people, as they are known today, came to settle in the southern part of present-day Zimbabwe at Ntabazinduna near Bulawayo around 1838-1840. The southwestern parts of Zimbabwe are today referred to as the Matabeleland provinces. Mzilikazi continued to expand his nation by raiding and incorporating many tribes into his political system. It is in Zimbabwe that the Ndebeles assimilated by far the largest number of peoples. These included mainly the Nyubis, Kalangas, Nanzwas, Nambyas, and to some extent the Tongas and some Shona tribes. Most of these were previously under rulers known as the Mambo and hence in Ndebele they were referred to as AbakaMambo, that is, 'Mambo's people' (see Hadebe 2002).

The name Ndebele therefore did not refer to a single tribe but to a multiethnic nation. Within the newly-found Ndebele nation which was then a kingdom, the Sothos outnumbered the Khumalos (or Ngunis) while the AbakaMambo far outnumbered both the Khumalos and the Sothos. The original Khumalo group referred to themselves as AbeZansi meaning 'those from the south', while the Sotho group was known as AbeNhla meaning 'those from the 
north' and lastly the rest of the majority were AbakaMambo. In spite of their numerical superiority, the incorporated groups learnt the Nguni language that is today called IsiNdebele or simply Ndebele.

Whether the language spoken by the original Khumalo clan that rebelled against the Zulu kingdom was Zulu or not, cannot now be easily ascertained. What is possible to demonstrate today is the close affinity between the Zulu and the Ndebele languages. The languages are mutually intelligible and share probably over $85 \%$ of their lexicon. A number of views have been put forward to explain this similarity between the two languages. The predominant view is that Ndebele is a dialect of Zulu. For instance, Pelling (1971: 3) writes: "Ndebele, while still correctly regarded as a dialect of the Zulu cluster, has diverged even further from standard Zulu ..." One possibility, although not popular, is that Ndebele is not a dialect of Zulu but both are sister languages with a common ancestor, which is proto-Nguni.

\section{Language Change}

In language contact studies, languages are presumed to come into contact with each other. In actual fact, it is always the speakers of the languages who are in contact. Their attitudes towards each other will influence the way they speak. It is, however, convenient for those who study language simply to speak about languages as though they had a life of their own.

Contact between people speaking different languages can have a wide variety of outcomes. In some cases only a few words are borrowed, in others whole new languages may be formed. The results of such contact differ according to several factors, including the length and intensity of contact between the groups, the types of social, economic and political relationship between them, the functions which communication between them must serve, and the degree of similarity between the languages they speak.

Most languages, including Ndebele, have been influenced at one time or another by contact, resulting in varying degrees of transfer of features from one to the other. Transfer of some features sometimes does not even require speakers of the different languages to have actual contact since it can be accomplished through book learning by teachers who then pass on the new vocabulary to other speakers via literature, religious texts, dictionaries, and so on.

As has been stated above, when the Khumalo clan left Zululand they had contact with other tribal groups. Between 1822 and 1837 the Ndebeles sojourned in the present Gauteng province. One phenomenon associated with their stay in the former Transvaal region was contact with missionaries. The London Missionary Society had established a mission station at Kuruman among the Tlapings. Although the Ndebeles did not generally embrace the Christian faith, some Tswana words from Christianity found their way into the Ndebele language. The following are some examples: 
EXAMPLE A

(i)

\begin{tabular}{|l|l|l|}
\hline Sotho Name & Ndebele Adoptive & English Equivalent \\
\hline Modimo & uMlimu & God \\
\hline
\end{tabular}

It should be noted that this "new" Ndebele word does not refer to God's greatness which is captured by $u$ Nkulunkulu in Ndebele.

(ii)

\begin{tabular}{|l|l|}
\hline Sotho Name & Adopted Ndebele Name \\
\hline Motlokwa & Mdlongwa \\
\hline Tau & Dawu \\
\hline Mokgatla & Mnkandla \\
\hline Nare & Nyathi \\
\hline
\end{tabular}

(iii)

\begin{tabular}{|l|l|}
\hline English Word & Ndebele Word \\
\hline two shillings & isikhwitshimana \\
\hline two shillings and six pence & ingogo \\
\hline one shilling & iloso \\
\hline six pence & ingcili \\
\hline one penny & indibilitshi \\
\hline sugar & umangungu \\
\hline
\end{tabular}

Despite the rapidly expanding world of the Ndebeles following the introduction of numerous material items, their language matched these changes. New Ndebele words were coined to cope with these.

The Tswana people who were incoporated into the fast-growing Ndebele empire abandoned their language in preference of Ndebele. Even their tribal names were changed to sound more like Ndebele names as demonstrated in the second part of Example A. Change was inevitable, and it favoured the dominating tribe, the Ndebele. Trade is said to have intensified in the Transvaal and coins were introduced and appropriately named as illustrated in the third part of Example A.

One of the greatest changes to the Ndebele language was wrought after the group's arrival in Zimbabwe. As has been stated above, this was the time when they had come into contact with the Nyubi, Kalanga, Nanzwa, Nambya, Tonga and some Shona tribes. Some changes resulting from contact between the Shona and the Kalanga groups are as follows:

\section{EXAMPLE B}

(i)

\begin{tabular}{|l|l|l|}
\hline Ndebele & Shona & English \\
\hline $\begin{array}{l}\text { Umuntu umile* } \\
\text { Umuntu umi }\end{array}$ & Munhu amire & A person is standing \\
\hline
\end{tabular}




\begin{tabular}{|l|l|l|}
\hline $\begin{array}{l}\text { Samukele } \\
\text { Sethule }\end{array}$ & Tigashire/Tigamuchire & Welcome \\
\hline $\begin{array}{l}\text { Hambisa* } \\
\text { Tshitsha }\end{array}$ & Fambisa & Hurry \\
\hline
\end{tabular}

Words marked by an asterisk represent constructions influenced by Shona (Hadebe 2002).

Another example of Shona influence is the use of the honorific plural or pronouns of power in the Ndebele language. Examples are:

(ii)

\begin{tabular}{|l|l|}
\hline Ndebele & Shona \\
\hline $\begin{array}{l}\text { Salibonani* } \\
\text { Sakubona }\end{array}$ & Mhoroi \\
\hline $\begin{array}{l}\text { Linjani* } \\
\text { Kunjani }\end{array}$ & Makadii \\
\hline
\end{tabular}

Words marked by an asterisk represent constructions influenced by Shona (Hadebe 2002).

\subsection{Vocabulary Change}

Language change can also result from a people going through a certain crisis in its history. New vocabulary is coined to describe the existing phenomenon. Carter and McCarthy (1988: 19) state: "The vocabulary of a language is in constant flux; old items drop out, new terms come in, and as the new replace and augment the old, so the internal relations of the whole set alter." The lexicographer is caught in the dilemma where words are coming into the language while others are dropping out. In the Ndebele-speaking provinces of Zimbabwe the Ndebele people went through the war of liberation (1972-1979) and the subsequent civil war (1982-1987). The following were some of the words that underwent semantic shift and some that came into the language.

EXAMPLE C

(i) Words that underwent a semantic shift

\begin{tabular}{|l|l|}
\hline Ndebele Word & Background \\
\hline umthengisi & $\begin{array}{l}\text { Before the war this word referred to a shopkeeper or any } \\
\text { salesperson. After having undergone pejorative changes, it } \\
\text { now refers to a traitor. }\end{array}$ \\
\hline umjibha & $\begin{array}{l}\text { This word referred to Zimbabwean migrant workers in Johan- } \\
\text { nesburg. Staying in crime-ridden Johannesburg and surviving } \\
\text { there, these workers were perceived to be brave and brilliant. } \\
\text { During and after the war, the word umjibha switched meaning } \\
\text { to refer to a male assistant to guerrillas, who helped in passing } \\
\text { information between guerrillas and villagers. }\end{array}$ \\
\hline
\end{tabular}




\begin{tabular}{|l|l|}
\hline abafana & During the war, villagers called guerrillas abafana (the boys)
\end{tabular}
to avoid being detected by Rhodesian informers.

(ii) Words coined during the war

\begin{tabular}{|l|l|}
\hline Ndebele Word & Source Word \\
\hline itororo & $\begin{array}{l}\text { The white Rhodesian government referred to the guerrillas } \\
\text { as 'terrorists'. }\end{array}$ \\
\hline amalwecatsha & $\begin{array}{l}\text { This word referred to the nature of guerrilla fighters: 'those } \\
\text { who fight while hiding'. }\end{array}$ \\
\hline
\end{tabular}

The guerrillas were trained and armed largely by the then socialist countries and independence was equated with a socialist revolution. Some terms related to the socialist ideology were brought into the Ndebele language.

(iii) Borrowed words

\begin{tabular}{|l|l|}
\hline Ndebele Word & Source Word \\
\hline ipovo & $\begin{array}{l}\text { The French word bourgeoisie, transliterated to refer to one } \\
\text { who grabs wealth. }\end{array}$ \\
\hline ibhesi & $\begin{array}{l}\text { Portuguese word for 'civilian population'. } \\
\text { Some Zimbabwean guerrillas were trained in the Portu- } \\
\text { guese-speaking countries of Angola and Mozambique. } \\
\text { They brought with them Portuguese slogans and words } \\
\text { that eventually found their way into Ndebele vocabulary. }\end{array}$ \\
\hline iphungwe & From English military base \\
\hline ikatutsha & From Shona pungwe \\
\hline ibhazuka & Derived from katucha \\
\hline u-akha & Derived from bazooka \\
\hline ikhiphu & $\begin{array}{l}\text { Derived from AK } 47 \text { rifle } \\
\text { During the war, the Rhodesian government created secu- } \\
\text { rity camps where villagers were detained. }\end{array}$ \\
\hline
\end{tabular}

\subsection{Lexical Engineering}

Lexical engineering is viewed by Singleton (2000: 152) as a discipline that "involves not only the coining of new expressions but also the modification or in some cases the suppression - or attempted suppression - of existing expressions". In Ndebele, there are a number of cases where some words have been coined while some have been suppressed, especially due to the influence of the Christian faith. Words that have come into the Ndebele vocabulary through the advent of Christianity include the following:

umfundisi (reverend and teacher)

Education was introduced to the Ndebeles by the missionaries who did preach- 
ing as well as teaching in their newly established schools. The preacher was also seen as a schoolteacher. Umfundisi is derived from the verb -fundisa (to teach). When the colonial government in Rhodesia began to build schools for Africans in the 1960s, teachers were hired who were not necessarily preachers. In Zimbabwe today, there no more exists an obvious link between education and the Church and teachers are seen independently from religious duties. The word umfundisi has now narrowed to refer only to a preacher. A teacher is called umbalisi, derived from -balisa (to help to read).

umtshumayeli (preacher)

Umtshumayeli is the other word for 'preacher'. As Ndebele traditional religion did not have a preacher, this word should have been coined to denote the Christian preacher. However, the verb -tshumayela (to preach) seems to have been in the language but it referred to narrating. Now the verb -tshumayela has shifted its meaning to refer exclusively to preaching.

umvangeli (evangelist); ivangeli (evangelism); -vangela (to evangelize)

The influence of the Christian faith has led to the transliteration of the word 'evangelism' to ivangeli in Ndebele, as well as to the formation of umvangeli (evangelist) and -vangela (to evangelise). These very common words now appear as if they are indigenous to Ndebele. Another word seemingly indigenous to Ndebele is isono (sin). It is now difficult to tell whether the word isono is a transliteration from the English 'sin' or whether it is derived from the Ndebele verb -ona (to err). The noun derived from the verb -ona is isono (literally a wrong/crime). The word isono ( $\sin$ ) has a religious connotation of a very evil deed that is forbidden.

umbhabhathizo (baptism); -bhabhathiza (baptize); umbhabhathizi (a Baptist)

These three words which are now extensively used in Ndebele, are an indisputable part of the Ndebele vocabulary although it is known that they are transliterations from English.

Some words have shifted in meaning from what they originally meant and have taken a certain religious connotation.

-khonza (to worship)

In Ndebele, the word -khonza means 'to be loyal' or 'to like'. If a subject is loyal to his master, the Ndebele would say uyamkhonza (is very loyal). If one is very fond of someone or something, uyamkhonza is also used. For instance, the Ndebele might say uyikhonzile intombi yakhe (he is very fond of his girlfriend). This sense of the word -khonza is now rarely used and is even excluded from the 
ISN, the sense of 'worship' being the only sense given. The Christians, however, do not confine -khonza to their worship but extend it to the traditional Ndebele religion as well. In Zimbabwe, Christianity is viewed as superior to and thus opposes and denigrates African religions. The traditional Ndebele belief system says there is an almighty creator of the earth uNkulunkulu (the Great, Great One). However, the Ndebele did not pray to or communicate with $u$ Nkulunkulu directly but instead they appeased their ancestral spirits in the event of misfortunes. The Christians, on the contrary, are very much opposed to any rites or ceremonies related to the traditional Ndebele religion. The Christians refer to these rites as ancestor worship - ukukhonza amadlozi (to worship spirits). Those who practice the traditional Ndebele religion do not consider their acts as ukukhonza (worship) but as the atonement of angry spirits. The Christians have stigmatised the traditional Ndebele religion by deliberately extending the term -khonza to include ceremonies and rituals not being worshipping at all.

\section{-khuleka (to pray)}

This word has also shifted in meaning to refer to praying. In Ndebele society when you visit a home, you have to announce your presence at the gateby shouting and saying E Kuhle! (All is well!). The head of the homestead will shout in response and grant you permission to enter his home (Hadebe 2000). This act is called ukukhuleka (announcing your presence). Christians believe that in praying they are asking God to listen to their requests and the Ndebele church-goers equate this act to announcing one's arrival at a homestead ukukhuleka. Nowadays, the Ndebele people have adopted the Western way of knocking at somebody's door. As the practice of the traditional ukukhuleka has vanished in the urban centres, and the word now only refers to praying.

isiphambano (a cross)

isidlo (holy communion)

The Roman Catholic Church is the largest Christian denomination in Zimbabwe, and these two words have therefore become very important among the Ndebele Christians. The word isiphambano (a cross) is derived from the verb -phambana (to cross things), while isidlo (holy communion) is derived from the verb - dla (to eat). These two words are now part of the Ndebele vocabulary, being some of the many words most speakers take for granted as indigenous Ndebele words, so that their origins are hardly ever questioned.

\subsection{Lexical Engineering with Reference to Loanwords}

Hadebe (2002) observes that there was a period in the 1970s when loanwords from English were being avoided in the Ndebele language. This period of purism saw the substitution of loanwords from English by words believed to be indigenous as they were taken from Zulu. It should be noted that most Nde- 
bele speakers look to Zulu as the source of indigenous vocabulary. It is unfortunate that this purism did not purge Ndebele of European loanwords as intended but substituted English by Afrikaans as the source language. That does not mean that Ndebele speakers preferred Afrikaans to English, but they adopted these Afrikaans words via Zulu believing them to be indigenous Zulu words. The cause for these Afrikaans adoptions was the contact of the Zulu people with the Afrikaners.

\section{EXAMPLE D}

(i) Adopted words from Afrikaans

\begin{tabular}{|l|l|l|}
\hline Ndebele Word & Afrikaans Word & English Equivalent \\
\hline ifasiteli & venster & window* $^{*}$ \\
\hline itafula & tafel & table* \\
\hline ipulazi & plaas & farm $^{*}$ \\
\hline isitulo & stoel & chair \\
\hline ibhatshi & baadjie & jacket \\
\hline ijazi & jas & coat \\
\hline umfolo & voor & furrow \\
\hline umjaho & jaag & chase \\
\hline
\end{tabular}

The English words marked by an asterisk have the Ndebele forms shown under (ii) as equivalents. These were discouraged, while the Ndebele forms originating from Afrikaans given under (i) were promoted.

(ii)

\begin{tabular}{|l|l|}
\hline English Word & Ndebele Word - Avoided \\
\hline window & iwindi \\
\hline table & ithebuli \\
\hline farm & ifamu \\
\hline
\end{tabular}

Ndebele has not all the time been permissive to foreign influence as is shown by this deliberate suppression of English vocabulary items. Unfortunately ordinary speakers are not aware of the false basis of this purism.

In an attempt to use indigenous words as opposed to loanwords, a number of words were coined in Ndebele to replace the loanwords. Some of these include untshelelezane (bicycle) as opposed to the loanword ibhayisikili (bicycle), inkolo yomlilo (motor car) as opposed to imota (motor car) and umbalisi (teacher) as opposed to utitshala (teacher). All these words are lemmatised in the ISN, although the Ndebele language corpus shows the prevalent use of the loanwords. This lexical engineering is a phenomenon not exclusive to Ndebele but common to languages in general. It is part of an attempt by society or sections of society to control vocabulary change.

There has also been influence from other African languages in contact with Ndebele, especially Shona, Kalanga, Sotho, Venda, Nambya and Tonga. A number of words currently taken for granted to be Ndebele originally came 
from Shona, Kalanga or Sotho. One most debated word is the verb -kwanisa (be able). Language purists and teachers would insist that the word -enelisa (be able) should be used instead, being considered good and appropriate language. The ISN did not lemmatise -kwanisa even though it is more common than -enelisa for fear of it being labelled as 'bad language'. There are also words with sounds that are resisted by some sections of the Ndebele-speaking community, especially the elderly and those of Nguni origin. The affricate /dz/ is not original to Ndebele. Currently, however, there are a number of words with this sound. Instead of articulating the sound $/ \mathrm{dz} /$ some speakers replace it with $/ \mathrm{j} /$. Most words with these sounds have become variants as shown in the following examples:

$$
\begin{aligned}
& \text { dzikama - jikama (be steady) } \\
& \text { ubudzugwe - ubujugwe (type of mushroom) } \\
& \text {-dzimila - jimila (to be lost and have memory lapses) }
\end{aligned}
$$

These examples illustrate the problems encountered by Ndebele lexicographers in headword selection and in defining.

\section{The Lexicographical Terminographical Interface}

Seemingly lexicography and terminography have much in common. They are both concerned with describing lexical items in a user-friendly format within a dictionary. The main concern of both lexicography and terminography is thus the word.

Lexicography is often defined as the science of dictionary making. Svensen (1993: 1) defines lexicography as a branch of applied linguistics which consists in observing, collecting, selecting, and describing units from the stock of words and word combinations in one or more languages.

The purpose of terminography is to identify and analyze lexical items used in specialized domains of knowledge, such as commerce, medicine, law and computing. In principle, all domain-specific terms are of interest. In practice, terminographers are mostly preoccupied with 'new' terms: as domains change or grow, often at a startling pace, terminographers must document the associated lexical changes.

Whereas lexicography is essentially a semasiological enterprise, that is, starting with words and trying to explain their meanings, terminography has a significant onomasiological component, that is, starting with the analysis of a domain in order to establish its limits, relations to other domains and subdomains. Since understanding a domain means understanding the domain concepts, conceptual analysis is considered the cornerstone of terminography (Meyer and Eck 1996; Picht and Draskau 1985). Lexicography therefore deals with general language while terminography is domain specific.

As they should be complementary, these two disciplines are vital to each 
other. The challenge therefore faced by lexicographers in Zimbabwe is the absence of terminography as a discipline. The possibility must be there for words created by terminographers to be standardized by way of including them in dictionaries. Although it does not exist as a recognized discipline in Zimbabwe, terminography is actively practised among the Ndebele people, as has been demonstrated in this article.

Through the production of a corpus-based Ndebele monolingual dictionary, the ISN, lexicographers have taken advantage of the closeness of these disciplines to standardize terminology that has originated with the people. Because of language contact and the resultant lexical change, Ndebele has rapidly changed and continues to change. The lack of terminography as a discipline has meant that words are not quickly identified and standardized in their various domains so that they can be put to use as part of the core vocabulary.

The question could be asked: Should the lexicographer exclude these unstandardized lexical items? The answer is no. The Ndebele lexicographer has had to double as both terminographer and lexicographer to bring these lexical items into the mainstream vocabulary, giving them a new tag as formal words.

The following is a sample of words which found a new status within the Ndebele lexicon. These words were introduced in the ISN for purposes of standardizing them because the corpus demonstrated that they overwhelmingly appear in the everyday use of the language. Of these terms it may be stated quite rightly, that they can no longer be excluded from the Ndebele vocabulary.

\section{EXAMPLE E}

ipasipoti bz 5. Ipasipoti lugwadlana olunikwa umuntu nguHulumende, olutshengisa ukuthi umuntu ulemoumo yokuhamba kwamanye amazwe, kanye lokuthi ungubani lokuthi uyisizalwane saliphi ilizwe.

(passport N A passport is an official document issued by the government, which contains your personal details, which you need to show when you enter or leave a country.)

imoningigawuni bz 5. Imoningigawuni yigawuni umuntu ayigqokayo lapho evuka.

(morning gown $\mathrm{N}$ A morning gown is a long loose robe that is worn usually in the mornings by someone who has just woken up.)

amavolontiya bz 6. Amavolontiya ngamabutho ayelwela imali aqhatshwa nguRozi ukuba achithe umbuso kaLobhengula ngo 1893.

(volunteers N Volunteers are people who were conscripted and paid by Rhodes to destroy King Lobhengula's rule in 1893.)

bhekha sz mwa. Ukubhekha yikipheka ngewoveni into enjengesinkwa loba amakhekhe.

(bake VB To bake food like bread is to cook it in an oven without using extra liquid or fat.) 
itshampiyoni bz 5. Itshampiyoni ngumuntu onguye othethe isicoco saphezulu kumbe onqobileyo emdlalweni othize. Fan ingqungquthela.

(champion $\mathrm{N}$ A champion is someone who has won the first prize in a competition.)

\section{Conclusion}

It has been demonstrated that language contact naturally leads to language change through borrowing or lexical engineering. The result of this process is the addition of new words to the lexicon that need to be standardized and be recognized as formal. Ndebele lexicography has taken an important step towards formalizing new words in its lexicon.

\section{Bibliography}

Carter, R. and M. McCarthy. 1997. Vocabulary and Language Teaching. London/New York: Longman.

Hadebe, S. 2000. Developing Terminology in African Languages with Special Reference to Ndebele. Chiwome, E.M. et al. (Ed.). 2000. Indigenous Knowledge and Technology in Africa and Diasporan Communities: 225-231. Harare: Mond Publishers.

Hadebe, S. 2002. The Standardisation of the Ndebele Language through Dictionary Making. Unpublished D.Phil. Thesis. Harare and Oslo: University of Zimbabwe and University of Oslo.

Hadebe, S. (Ed.). 2001. Isichazamazwi SesiNdebele. Harare: College Press.

Khumalo, L. 2004. A General Introduction to Ndebele Grammar. Cape Town: CASAS.

Meyer, I., K. Eck and D. Skuce. 1997. Systematic Concept Analysis within a Knowledge-based Approach to Terminology. Wright, Sue-Ellen and Gerhard Budin (Eds.). 1997. Handbook of Terminology Management. Vol. 1: 98-118. Amsterdam/Philadelphia: John Benjamins.

Pelling, J. 1971. A Practical Ndebele Dictionary. Harare: Longman Zimbabwe.

Picht, H. and J. Draskau. 1985. Terminology: An Introduction. Guildford: University of Surrey.

Singleton, D. 2000. Language and the Lexicon: An Introduction. London: Arnold. 